\title{
Interleukin-8 and Tumor Necrosis Factor-Alpha Are Increased in Minimal Change Disease but Do Not Alter Albumin Permeability
}

\author{
Min Hyun Cho ${ }^{a}$ Hwan Seok Lee ${ }^{a}$ Byung Ho Choe ${ }^{a}$ Soon Hak Kwon ${ }^{a}$ \\ Ki Young Chung ${ }^{b}$ Ja Hoon Koo ${ }^{a}$ Cheol Woo Ko ${ }^{a}$ \\ aDepartment of Pediatrics, Kyungpook National University Hospital, and ${ }^{\mathrm{b} B i o m e d i c a l ~ R e s e a r c h ~ I n s t i t u t e, ~ T a e g u, ~}$ \\ South Korea
}

\section{Key Words}

Minimal change nephrotic syndrome - Interleukin-8 . Tumor necrosis factor-alpha - Glomerular epithelial cell . Albumin permeability

\begin{abstract}
Aims: Minimal change disease (MCD) is the most common primary nephrotic syndrome in children. Some suggested that interleukin-8 (IL-8) and tumor necrosis factor$\alpha$ (TNF- $\alpha$ ) are involved in the pathogenesis of MCD. This study was done to see changes of plasma and urinary IL-8, TNF- $\alpha$, and their effects on determination of permeability of glomerular basement membrane (BM) contributed by heparan sulfate proteoglycan (HSPG). Methods: Study patients consisted of 19 biopsy-proven MCD children aged 2-15 years old. Both plasma, urinary IL-8 and TNF- $\alpha$ were measured. Employing the Millicell system, IL-8 and TNF- $\alpha$ were screened for the permeability factors. We examined whether IL- 8 and TNF- $\alpha$ regulated BM HSPG gene expression and HS synthesis in the glomerular epithelial cells (GECs). Results: Urinary IL-8 during relapse was significantly increased when compared with that of during remission or controls $(13,996 \pm 2,811$ vs. $2,941 \pm 373,5,331 \pm 640 \mathrm{ng} / \mathrm{mg} \cdot \mathrm{cr})(\mathrm{p}<0.05)$. Urinary TNF- $\alpha$ during relapse was also significantly increased $(364.4 \pm 51.2$ vs. $155.3 \pm 20.8,36.0 \pm 4.5 \mathrm{ng} / \mathrm{mg} \cdot \mathrm{cr})(\mathrm{p}<$ 0.05). Plasma IL-8 during relapse was significantly increased compared to that during remission(1.19 \pm 0.62
\end{abstract}

vs. $0.51 \pm 0.42 \mathrm{ng} / \mathrm{ml})(\mathrm{p}<0.05)$. However, the negative results were obtained in the permeability assay using the Millicell system. No difference was seen in BM HSPG gene expression and HS synthesis in the GECs. Conclusion: Therefore, it seems that both IL-8 and TNF- $\alpha$ may not play a disease-specific role in the pathogenesis of MCD.

Copyright $@ 2003$ S. Karger AG, Basel

\section{Introduction}

Minimal change disease (MCD) is the most common cause of nephrotic syndrome in children, accounting for $90 \%$ of cases under the age of 10 and more than $50 \%$ in older children [1]. It has been proposed that MCD reflects a disorder of T-lymphocytes. These T cells, which are presumably sensitive to corticosteroid and other immunosuppressants such as cyclosporin and cyclophosphamide are thought to release a cytokine that injures the glomerular epithelial cells $[2,3]$. Epithelial cell damage may lead to albuminuria in MCD by altering the metabolism of polyanion such as heparan sulfate proteoglycan (HSPG); these polyanions constitute most of the normal charge barrier to the glomerular filtration of macromolecules such as albumin. The albuminuria in MCD is mainly due to loss of charge-selectivity in the glomerular wall $[4,5]$. The acute infusion of plasma [6-8], supernatants [8-11], or fraction of supernatants $[12,13]$ from cultured periph-

\begin{tabular}{ll}
\hline KARGER & ( ) 2003 S. Karger AG, Basel \\
0250-8095/03/0234-0260\$19.50/0 \\
$\begin{array}{l}\text { Fax +4161306 1234 } \\
\text { E-Mail karger@karger.ch } \\
\text { www.karger.com }\end{array}$ & $\begin{array}{l}\text { Accessible online at: } \\
\text { www.karger.com/ajn }\end{array}$
\end{tabular}

Professor Cheol Woo Ko, MD, PhD

Department of Pediatrics

Kyungpook National University Hospital

50, Samduk-2 Ga, Joong-Gu, Taegu 700-721 (South Korea)

Tel. +8253420 5715, Fax +8253425 6683, E-Mail cwko@knu.ac.kr 
eral blood mononuclear cells (PBMCs) isolated from patients with MCD into rats has been associated with an increased urinary albumin excretion and/or a decrease in number of anionic sites in the glomerular basement membrane (GBM) [6, 7, 9-13]. The identity of permeability factor is still uncertain. Data from some investigators have suggested that interleukin-8 (IL-8) and tumor necrosis factor- $\alpha$ (TNF- $\alpha$ ) may be active factors as determined by some experimental models of MCD or synthesis/gene expression in patients with MCD [14-16].

IL-8 is a cytokine originally purified from the supernatant of human monocytes stimulated with lipopolysaccharide, but also known to be secreted by lymphocytes, endothelial, and tubular cells [17]. IL-8 was primarily thought to be a neutrophil chemotactic factor [14]. Some researchers have suggested that PBMCs from MCD patients in relapse secrete IL- $8[14,15,18]$. IL- 8 is elevated in the serum and the supernatant of PBMC from patients with MCD. They have also observed that in vivo infusion of IL-8 into the renal artery also induced albuminuria and increased the ${ }^{35}$ sulfate incorporation into the GBM [19].

Tumor necrosis factor- $\alpha$ (TNF- $\alpha$ ), a cytokine that elicits a wide spectrum of inflammatory and metabolic activities, is mainly produced by monocytes and macrophages, but also by a large variety of cells [20]. It has been suggested that TNF- $\alpha$ could participate in the pathogenesis of glomerular damage in various models of nephritis [2123]. Recent data suggested that patients with MCD had higher serum TNF- $\alpha$ levels and TNF- $\alpha$ production by monocytes than patients in remission and controls. TNF- $\alpha$ mRNA expression of PBMCs in patients with activity were increased compared to controls and patients in remission [16].

The purpose of this study was to assess the direct effect of these two cytokines, IL- 8 and TNF- $\alpha$, on glomerular epithelial cells (GECs) that are thought to be the target cell in the pathogenesis of MCD. We measured both serum and urine levels of these two cytokines in remission and relapse from children with MCD. IL- 8 and TNF- $\alpha$ were also tested whether they made a change in the permeability of GEC monolayers. And, GECs were directly exposed to IL- 8 or TNF- $\alpha$, then, BM HSPG gene expression and HS synthesis were determined.

\section{Materials and Methods}

\section{Patients}

Nineteen children ( 11 boys and 8 girls) with biopsy-proven MCD, as defined by the International Study of Kidney Disease in Children (ISKDC) [1], were included in the study. Their ages ranged 2-15 years (average 9.5 years). Age and sex-matched 10 healthy children were also included as healthy controls. Their ages ranged 3-14 years (average 9.8 years). Relapse of the nephrotic syndrome was defined as massive proteinuria $\left(>40 \mathrm{mg} / \mathrm{m}^{2} / \mathrm{h}\right.$ in 17 patients, $>2.0$ urinary protein to creatinine ratio in 2 patients) and a low serum albumin level $(2.5 \mathrm{~g} / \mathrm{dl})$. We estimated the adequacy of urine collection by calculating total creatinine content in the collected urine. Because of inadequate 24-hour urinary collection in 2 patients, they were defined as relapse by urinary protein to creatinine ratio $>2.0$. Serum and urine were sampled both in remission and relapse, and kept at $-70^{\circ} \mathrm{C}$.

\section{Glomerular Epithelial Cells}

GECs cloned from primary rat glomerular cultures were obtained from J.L. Kreisberg (San Antonio, Tex., USA); the methods of cell cloning and characterization have been described previously [24]. The differential identification was based on the following criteria: (1) cobblestone appearance of the cell monolayer; (2) presence of microvilli; (3) presence of junctional complexes suggestive of tight junctions; (4) absence of myosin, and (5) formation of 'domes' on plastic dishes when the monolayer was kept beyond confluence, suggesting unidirectional transport of sodium and water, a characteristic of polar cells such as epithelial cells. Further characterization included sensitivity to puromycin aminonucleoside, positive staining for Heymann antigen (gp 330) and heparan sulfate proteoglycan core protein, and negative staining for factor VIII $[25,26]$. Discussion of the visceral epithelial origin of these cells versus a parietal origin has been presented previously [26].

\section{Measurement of Interleukin-8 and Tumor Necrosis Factor- $\alpha$}

Both plasma and urine IL- 8 and TNF- $\alpha$ were determined using an IL-8 ELISA and a TNF- $\alpha$ ELISA kit (Endogen, Inc., Mass., USA). $50 \mu \mathrm{l}$ of standards or samples were added in duplicate. The plate was covered and incubated at room temperature $\left(20-25^{\circ} \mathrm{C}\right)$ for $1 \mathrm{~h}$. The plate was washed three times with wash buffer provided with the kit. $50 \mu \mathrm{l}$ of the biotinylated antibody reagent were added to each well being utilized. The plate was covered and incubated for $1 \mathrm{~h}$ at room temperature. The plate was washed three times with wash buffer. Streptavidin-HRP concentrate was diluted in dilution buffer and $100 \mu \mathrm{l}$ of this solution was added to each well. The covered plate was incubated at room temperature for $30 \mathrm{~min}$. Then the plate was washed three times with wash buffer. $100 \mu$ of premixed TMB substrate solution was added to each well. The plate was developed at room temperature in the dark for $30 \mathrm{~min}$. The reaction was stopped by adding $100 \mu \mathrm{l}$ of the provided stop solution to each well. The absorbance of the plate was read on a plate reader at 450-550 nm. Results were calculated using graph paper or curve fitting statistical software.

\section{Permeability Assay Using a Semi-Permeable Membrane}

(the Millicell System)

GECs were grown on the surface of cellulose semi-permeable membrane (Millicell-HA, $0.45 \mu \mathrm{m}$ culture plate insert, $12 \mathrm{~mm}$ diameter, Millipore Corp., Mass., USA). After confluence of GECs, the medium was changed into fresh medium containing $1,000 \mathrm{ng} / \mathrm{ml}$ of IL-8, TNF- $\alpha$ or sera from children with MCD, then, cells were incubated for $48 \mathrm{~h}$ at $37^{\circ} \mathrm{C}$ in a $5 \% \mathrm{CO}_{2} / 95 \%$ air. Human serum albumin (Sigma Corp., Mo., USA) were added into the basolateral compartment. And the amount of human serum albumin (HSA) filtered into apical chambers was studied using an Albumin RIA kit (Immunotech 
Corp., Prague, Czech Republic) by obtaining 60- $\mu$ l aliquot sample from the apical side at $18 \mathrm{~h}$ after the addition of HSA. A typical experiment also included a negative control (Millicells included with medium alone) and a positive control (Millicells treated with $95 \%$ ethanol for 5 min followed by washing and replacement with fresh medium as Pegoraro et al. [27] did).

\section{Extraction of Total RNA}

Rat GECs were grown to confluence in RPMI 1640 media supplemented with $10 \%$ heat-inactivated fetal bovine serum (FBS), $15 \mathrm{mmol} / 1 \mathrm{HEPES}, 0.66 \mathrm{U} / \mathrm{ml}$ insulin, $100 \mu \mathrm{g} / \mathrm{ml}$ streptomycin, and $100 \mathrm{U} / \mathrm{ml}$ penicillin at $37^{\circ} \mathrm{C}$ in $5 \% \mathrm{CO}_{2} / 95 \%$ air. Either IL-8 or TNF- $\alpha$ (Endogen Inc., Mass., USA) was added at concentrations of 0 , 10,100 , and $1,000 \mathrm{ng} / \mathrm{ml}$. Total RNA was extracted at 24 and $48 \mathrm{~h}$ after adding IL-8 or TNF- $\alpha$ by Chomczynski and Sacchi's [28] method.

\section{Estimation of BM HSPG $m R N A$ Expression in Rat GECs}

Extracted RNA was reverse-transcribed using random primers (cDNA cycle kit, Invitrogen Corp., Wisc., USA). BM HSPG-specific primers were synthesized from published sequences of domain-I of BM HSPG cDNA [29, 30]. The forward and reverse primers with sequences 5'-GCTGAGGGCCTACGATGG-3' and 5'-TGCCCAGGCGTGGAACT-3', respectively, were synthesized. Beta-actin was used as internal control, and the forward and reverse primers with sequences 5'-ATCTGGCACCACACCTTCTACAATGAGCTGCG-3' and 5'-CGTCATACTCCTGCTTGCTGATCCACATCTGC-3', respectively, were synthesized. A multiplex polymerase chain reaction (PCR) using BM HSPG-specific and $\beta$-actin primers was performed.

PCR was performed in 25 cycles, each cycle consisting of denaturation at $94^{\circ} \mathrm{C}$ for $1 \mathrm{~min}$, annealing of primers of cDNA at $56^{\circ} \mathrm{C}$ for $2 \mathrm{~min}$, and extension at $72^{\circ} \mathrm{C}$ for $1.5 \mathrm{~min}$. The reaction products were separated on TBE, $1.2 \%$ agarose gel. The area and size of each band on the $1.2 \%$ agarose gel was analyzed by a gel documentation system (Alphainnotech Corp., Calif., USA).

\section{Estimation of HS Synthesis in Rat GECS}

GEC was labeled with $200 \mu \mathrm{Ci} / \mathrm{ml}$ of ${ }^{35} \mathrm{SO}_{4}$ (ICN Radiochemicals, specific activity $43 \mathrm{mCi} / \mathrm{mg} \mathrm{S}$, carrier-free) for 12 and $24 \mathrm{~h}$ and for the last 24 of $48 \mathrm{~h}$ incubation. The cell layers were dissolved in immunoprecipitation buffer containing $20 \mathrm{~m} M$ TRIS, pH 7.5, $0.15 M \mathrm{NaCl}, 4 \mathrm{~m} M$ EDTA, $1 \% \mathrm{NP}-40,1 \mathrm{~m} M$ sodium orthovanadate, $1 \mathrm{~m} M$ PMSF, $100 \mathrm{~m} M$ 6-aminohexanoic acid, $5 \mathrm{~m} M$ benzamidine $\mathrm{HCl}$. The protein content was estimated using Biorad protein assay (BioRad, Calif., USA). Immunoprecipitation was performed employing a modified method of Ledbetter et al. [31], as previously described, using equal amounts of cell protein $(50 \mu \mathrm{g})$ and a specific antibody against rat GBM heparan sulfate side chain (UBI, Calif., USA). The radioactivity in the immunoprecipitates was measured in a beta counter.

\section{Statistics}

Data are presented means \pm SD unless otherwise noted. Statistical analyses were performed using the software SPSS (version 11; SPSS Inc., Chicago, Ill., USA). Statistical significance (defined as $\mathrm{p}<$ 0.05 ) was evaluated with paired t test and non-parametric MannWhitney U test where appropriate.
Table 1. Changes of urinary IL- 8 and TNF- $\alpha$ in children with MCD during relapse and remission

\begin{tabular}{lccc}
\hline & Relapse & Remission & Healthy controls \\
\hline IL-8 & $13,996 \pm 2,811^{*++}$ & $2,941 \pm 373$ & $5,331 \pm 640$ \\
& $(11,013-16,324)$ & $(2,523-3,291)$ & $(4,728-5,871)$ \\
TNF- $\alpha$ & $364.4 \pm 51.2^{*++}$ & $155.3 \pm 20.8^{+}$ & $36.03 \pm 4.5$ \\
& $(298.3-406.8)$ & $(128.5-168.6)$ & $(31.9-40.0)$ \\
\hline
\end{tabular}

$* \mathrm{p}<0.05$ compared to remission

$+p<0.05$ compared to healthy controls.

Parentheses are $95 \%$ CIs. Values given as $\mathrm{ng} / \mathrm{mg} \cdot \mathrm{cr}$.

Table 2. Changes of plasma IL- 8 and TNF- $\alpha$ in children with MCD during relapse and remission

\begin{tabular}{lccc}
\hline & Relapse & Remission & Healthy controls \\
\hline IL-8 & $1.19 \pm 0.62 *$ & $0.51 \pm 0.42$ & $0.77 \pm 0.31$ \\
& $(0.65-1.75)$ & $(0.14-0.85)$ & $(0.51-1.02)$ \\
TNF- $\alpha$ & $2.42 \pm 1.93$ & $1.95 \pm 1.62$ & $2.25 \pm 1.75$ \\
& $(0.63-4.01)$ & $(0.48-3.40)$ & $(0.40-3.81)$ \\
\hline
\end{tabular}

$* \mathrm{p}<0.05$ compared to remission.

Parentheses are $95 \%$ CIs. Values given as $\mathrm{ng} / \mathrm{ml}$.

\section{Results}

\section{Changes of Plasma IL-8, Urinary IL-8 Levels and \\ Plasma TNF- $\alpha$, Urinary TNF- $\alpha$}

Values of urinary IL- 8 and TNF- $\alpha$ were corrected by urinary creatinine in the same urine sample. Urinary IL-8 $(\mathrm{ng} / \mathrm{mg} \cdot \mathrm{cr})$ were $13,996 \pm 2,811,2,941 \pm 373$ and 5,331 \pm 640 in relapse, remission and healthy controls, respectively. Urinary IL-8 during relapse was significantly increased compared to healthy controls and remission $(\mathrm{p}<$ $0.05)$. Urinary TNF- $\alpha(\mathrm{ng} / \mathrm{mg} \cdot \mathrm{cr})$ were $364.4 \pm 51.2$, $155.3 \pm 20.8$ and $36.0 \pm 4.5$ in relapse, remission and healthy controls, respectively. Urinary TNF- $\alpha$ during relapse was significantly increased compared to healthy controls and remission $(\mathrm{p}<0.05)$ (table 1$)$.

Plasma IL-8 $(\mathrm{ng} / \mathrm{ml})$ was $1.19 \pm 0.62,0.51 \pm 0.42$ and $0.77 \pm 0.31$ in relapse, remission and healthy controls, respectively. Plasma IL-8 during relapse was significantly increased compared to that during remission $(\mathrm{p}<0.05)$. Plasma TNF- $\alpha(\mathrm{ng} / \mathrm{ml})$ was $2.42 \pm 1.93,1.95 \pm 1.62$ and $2.25 \pm 1.75$ in relapse, remission, and healthy controls, respectively. No significant changes of plasma TNF- $\alpha$ were observed in children with MCD during relapse and remission (table 2). 
Fig. 1. No difference was observed in the abundance of heparan sulfate proteoglycan mRNA in rat glomerular epithelial cells at various concentrations of interleukin- $8(0$, $10,100$, and $1,000 \mathrm{ng} / \mathrm{ml}) .1=24 \mathrm{~h} \mathrm{IL-8}$, $0 \mathrm{ng} / \mathrm{ml} ; 2=24 \mathrm{~h} \mathrm{IL-}-8,10 \mathrm{ng} / \mathrm{ml} ; 3=24 \mathrm{~h}$ IL-8, $100 \mathrm{ng} / \mathrm{ml} ; 4=24 \mathrm{~h}$ IL-8, 1,000 ng/ml; $5=48 \mathrm{~h} \mathrm{IL-}-8,0 \mathrm{ng} / \mathrm{ml} ; 6=48 \mathrm{~h}$ IL-8, $10 \mathrm{ng} / \mathrm{ml} ; 7=48 \mathrm{~h} \mathrm{IL-} 8,100 \mathrm{ng} / \mathrm{ml} ; 8=$ $48 \mathrm{~h} \mathrm{IL-8,} \mathrm{1,000} \mathrm{ng/ml.}$

Fig. 2. No difference was observed in the abundance of heparan sulfate proteoglycan mRNA in rat glomerular epithelial cells at various concentratons of TNF- $\alpha(0,10,100$, and $1,000 \mathrm{ng} / \mathrm{ml}) .1=24 \mathrm{~h} \mathrm{TNF}-\alpha, 0 \mathrm{ng} / \mathrm{ml}$; $2=24 \mathrm{~h} \mathrm{TNF}-\alpha, 10 \mathrm{ng} / \mathrm{ml} ; 3=24 \mathrm{~h}$ TNF- $\alpha$, $100 \mathrm{ng} / \mathrm{ml} ; 4=24 \mathrm{~h} \mathrm{TNF}-\alpha, 1,000 \mathrm{ng} / \mathrm{ml}$; $5=48 \mathrm{~h} \mathrm{TNF}-\alpha, 0 \mathrm{ng} / \mathrm{ml} ; 6=48 \mathrm{~h}$ TNF- $\alpha$, $10 \mathrm{ng} / \mathrm{ml} ; 7=48 \mathrm{~h} \mathrm{TNF}-\alpha, 100 \mathrm{ng} / \mathrm{ml} ; 8=$ $48 \mathrm{~h} \mathrm{TNF}-\alpha, 1,000 \mathrm{ng} / \mathrm{ml}$.
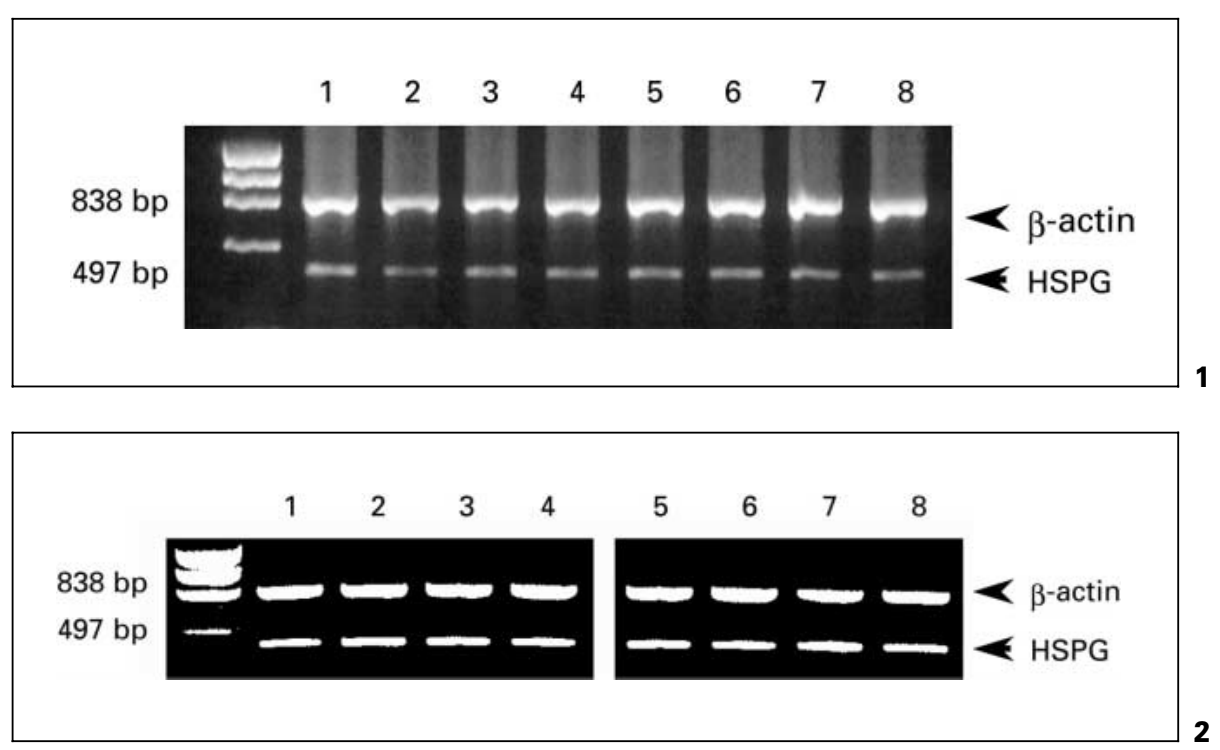

Table 3. Concentrations of human serum albumin leakage with IL-8, TNF- $\alpha$, sera from children with MCD and controls

\begin{tabular}{lc}
\hline IL- $8,1,000 \mathrm{ng} / \mathrm{ml}$ & $0.7 \pm 0.2$ \\
TNF- $\alpha, 1,000 \mathrm{ng} / \mathrm{ml}$ & $1.0 \pm 0.3$ \\
Sera from children with MCD & $27.7 \pm 2.4^{*}$ \\
Negative control & $0.6 \pm 0.2$ \\
Positive control & $46.0 \pm 1.7^{*}$
\end{tabular}

$* \mathrm{p}<0.05$ compared to negative controls.

Negative control: incubated with medium alone. Positive control: treated with $95 \%$ ethanol for $5 \mathrm{~min}$. Values given as $\mu \mathrm{g} / \mathrm{ml}$.

\section{Permeability Assay Using the Millicell System}

Sera from children with MCD caused marked albumin leakage across the GEC monolayers in the Millicell system $(\mathrm{p}<0.05)$. However, IL-8 and TNF- $\alpha$ did not induce greater albumin leakage than the negative control (table 3).

\section{Changes in Abundance of BM HSPG $m R N A$ in Rat GECs}

Rat GECs were incubated until confluence. Total RNA was extracted. The abundance of BM HSPG mRNA was measured at 24 and at $48 \mathrm{~h}$ after adding various concentrations of IL-8 or TNF- $\alpha$. At $24 \mathrm{~h}$ after adding IL-8, the percentages of BM HSPG mRNA expression to betaactin mRNA expression (\%) were $10.4 \pm 3.2,9.9 \pm 4.8$, $10.1 \pm 2.7$, and $9.6 \pm 3.1$ at concentrations of $0,10,100$ and $1,000 \mathrm{ng} / \mathrm{ml}$ of IL-8, respectively. At $48 \mathrm{~h}$ after adding
Table 4. Changes of heparan sulfate proteoglycan mRNA abundance in rat glomerular epithelial cells at various concentrations of IL- 8 and TNF- $\alpha$

\begin{tabular}{llrr}
\hline & & $24 \mathrm{~h}(\mathrm{n}=5)$ & $48 \mathrm{~h}(\mathrm{n}=5)$ \\
\hline IL-8 & $0 \mathrm{ng} / \mathrm{ml}$ & $10.4 \pm 3.2$ & $9.7 \pm 4.2$ \\
& $10 \mathrm{ng} / \mathrm{ml}$ & $9.9 \pm 4.8$ & $10.0 \pm 4.2$ \\
& $100 \mathrm{ng} / \mathrm{ml}$ & $10.1 \pm 2.7$ & $9.0 \pm 2.8$ \\
& $1,000 \mathrm{ng} / \mathrm{ml}$ & $9.6 \pm 3.1$ & $9.4 \pm 4.4$ \\
TNF- $\alpha$ & $0 \mathrm{ng} / \mathrm{ml}$ & $28.3 \pm 6.7$ & $33.7 \pm 3.4$ \\
& $10 \mathrm{ng} / \mathrm{ml}$ & $31.2 \pm 7.1$ & $29.5 \pm 5.1$ \\
& $100 \mathrm{ng} / \mathrm{ml}$ & $25.6 \pm 4.3$ & $31.5 \pm 2.8$ \\
& $1,000 \mathrm{ng} / \mathrm{ml}$ & $34.3 \pm 5.5$ & $37.3 \pm 4.3$ \\
\hline
\end{tabular}

Unit $(\%)=($ HSPG band density $/ \beta$-actin band density $) \times 100$.

IL-8, they were $9.7 \pm 4.2,10.0 \pm 4.2,9.0 \pm 2.8$, and 9.4 \pm 4.4 , at concentrations of $0,10,100$, and $1,000 \mathrm{ng} / \mathrm{ml}$ of IL-8, respectively. IL-8 did not induce significant changes of BM HSPG mRNA expression in rat GECs (table 4; fig. 1). Twenty-four hours after adding TNF- $\alpha$, the percentages of BM HSPG mRNA expression to beta-actin mRNA expression (\%) were $28.3 \pm 6.7,31.2 \pm 7.1,25.6$ \pm 4.3 , and $34.3 \pm 5.5$ at concentrations of $0,10,100$, and $1,000 \mathrm{ng} / \mathrm{ml}$ of TNF- $\alpha$, respectively. Forty-eight hours after adding TNF- $\alpha$, they were $33.7 \pm 3.4,29.5 \pm 5.1$, $31.5 \pm 2.8$, and $37.3 \pm 4.3$, at concentrations of 0,10 , 100 , and $1,000 \mathrm{ng} / \mathrm{ml}$ of TNF- $\alpha$, respectively. TNF- $\alpha$ did not induce significant changes of BM HSPG mRNA expression in rats GECs as IL-8 did not (table 4; fig. 2). 
Table 5. Synthesis of heparan sulfate in glomerular epithelial cells measured by immunoprecipitation using monoclonal antibody against heparan sulfate after adding IL- 8 and TNF- $\alpha$

\begin{tabular}{lcl}
\hline & $24 \mathrm{~h}(\mathrm{n}=5)$ & $48 \mathrm{~h}(\mathrm{n}=5)$ \\
\hline IL-8, $1,000 \mathrm{ng} / \mathrm{ml}$ & $97 \pm 7$ & $104 \pm 12$ \\
TNF- $\alpha, 1,000 \mathrm{ng} / \mathrm{ml}$ & $101 \pm 9$ & $106 \pm 6$ \\
Control & 100 & 100 \\
\hline
\end{tabular}

Control $=$ Neither IL- 8 nor TNF- $\alpha$ was added. Values are given as $\%$.

\section{HS Synthesis in Rat GECS}

Whether change in BM HSPG mRNA abundance caused by IL- 8 and TNF- $\alpha$ correlated with change in the synthesis of HS was examined by immunoprecipitation. There was no significant change in the synthesis of ${ }^{35} \mathrm{SO}_{4}$ labeled HS by IL- 8 or TNF- $\alpha$ (table 5 ).

\section{Discussion}

The identity of vascular permeability factors which are thought to exist in the blood of patients with MCD is still uncertain. Moreover, their mechanism of action has not been exactly defined in the pathogenesis of MCD. The acute infusion of plasma, supernatants, or fraction of supernatants from cultured PBMC isolated from patients with MCD in relapse into rats has been related to an increased urinary albumin excretion with or without a decrease in the number and density of anionic sites in the GBM. Recently, researchers have suggested that hemopexin, an acute-phase reactant, may be the active factor as determined by some experimental models of MCD [32, $33]$. Whether this finding is applicable to patients with MCD is unclear.

Some data have suggested that serum IL- 8 concentrations are increased in patients with MCD in relapse, and that IL-8 has been detected in the supernatants of cultured PBMC of the same patients [14, 15]. Albuminuria and increased catabolism of the GBM sulfated compounds have been observed when pooled supernatants from PBMC cultures of MCD patients in relapse were infused into rats [34]. Garin et al. [14] have shown that serum concentrations of IL-8 are increased in patients with MCD in relapse, and have suggested that it does not seem to be secondary to the nephrotic state, since patients with other types of nephrotic syndrome did not have detectable IL- 8 in their serum. We also observed a significant increase of serum and urinary IL-8 levels in patients with MCD during relapse. However, serum and urinary levels of IL-8 in both remission and controls are approximately $20-65 \%$ of serum and urinary IL- 8 concentrations in relapse. This is quite different from Garin's data showing no detectable serum IL-8 concentrations in other types of nephrotic syndrome. We measured IL-8 using the ELISA method instead of the RIA method which Garin [34] used. In addition, elevated serum IL-8 concentrations have been reported in patients with other types of glomerulonephropathies and proteinuria $[35,36]$.

Heparan sulfate proteoglycan constitutes most of the normal charge barrier to the glomerular filtration of macromolecules such as albumin, which is anionic in the physiologic $\mathrm{pH}$ range. The albuminuria in MCD is mainly due to loss of charge selectivity in the GBM $[4,5]$. The GECs synthesize most of heparan sulfate proteoglycan in the GBM [37]. These findings suggest that GECs are target cells in the pathogenesis of MCD, in other words, vascular permeability factor(s) secreted by peripheral mononuclear cells may directly injure the GECs, consequently, altering synthesis of $\mathrm{HS}(\mathrm{PG})$ by GECs, thus resulting in albuminuria. We observed that IL-8 at concentrations higher than those necessary to induce known lymphokine effects did not show any alteration in the BM HSPG gene expression and HS synthesis in the GECs. Human IL-8 has been demonstrated to have an effect on other species such as the rat [38]. The domain-I sequence of rat BM HSPG cDNA has 85 and $88 \%$ homology with murine and human sequences, respectively [37]. In our study all tested lymphokines were of human origin, and we used rat GECs.

Garin et al. [19] postulated that IL-8, by an unidentified mechanism, primarily augments the catabolism of the glomerular heparan sulfate proteoglycan. As a result, there is a compensatory increase in the synthesis of these compounds in their rat experimental study. However, Narita et al. [39] observed that IL-8 induced an increase of ${ }^{3} \mathrm{H}$-glucosamine in mesangial cells, not GECs, and they suggested that the elevated glomerular ${ }^{35}$ sulfate incorporation by IL- 8 does not represent the enhanced synthesis of heparan sulfate proteoglycan by GECs. We estimated the synthesis of heparan sulfate after adding IL-8 directly to GECs. No change was observed. Our previous study observed that serum from children with MCD rather diminished the expressions of heparan sulfate proteoglycan mRNA in rat GECs within $72 \mathrm{~h}$ [40].

The Millicell system has been used to study ion fluxes across tight junction in tubular epithelial cell monolayers, 
and some researchers modified it to study albumin fluxes using GECs [25, 41]. Adding polycationic substances such as protamine, cationic bovine gamma globulin (BGG), or glycated proteins increased the permeability of albumin across the GEC monolayer, and the addition of heparin decreased the albumin permeability induced by cationic BGG [41]. Pegoraro et al. [27] extended the use of this Millicell technique to search for permeability factors in patients with the idiopathic nephrotic syndromes. We tested the effects of IL- 8 and TNF- $\alpha$ in the Millicell system. The results were negative.

Many components are present in the GBM, the most abundant are type IV collagen chain $\alpha 3, \alpha 4, \alpha 5$, various laminin isoforms, and HSPGs. The main HSPGs that have been characterized until now are perlecan, agrin and recently collagen XVIII. With recently developed antibodies directed against the HSPG core protein and the HS side chain, some researchers demonstrated a decrease in $\mathrm{HS}(\mathrm{PG})$ staining in the GBM in SLE, diabetic nephropathy, etc. [42]. The number of studies dealing with HS(PG) synthesis in MCD is very limited. The studies in this field are necessary.

Bustos et al. [16] reported that patients with $\mathrm{MCD}$ and its variant had higher serum TNF- $\alpha$ levels and TNF- $\alpha$ production by monocytes than patients in remission and controls, and that the TNF- $\alpha$ mRNA levels of blood mononuclear cells in patients during relapse were increased compared to controls and to patients in remission. However, Suranyi et al. [43] described that TNF- $\alpha$ was significantly elevated in the plasma and urine of patients with focal segmental glomerulosclerosis and membranous glomerulonephropathy, and was normal in control subjects and patients with MCD. While Nakamura et al. [44] observed in vitro no effect on glomerular sulfate compounds, Shewring et al. [45] found that TNF stimulated mesangial cells to synthesize proteoglycans in a dose- and time-dependent manner. We observed that urinary $\mathrm{TNF}-\alpha /$ creatinine was significantly increased in relapse. However, no significant change in the plasma TNF- $\alpha$ during relapse was shown. In order to validate the role of TNF- $\alpha$ in the pathogenesis of MCD, we measured BM HSPG gene expression and HS synthesis in the GECs after adding TNF- $\alpha$. However, no significant change was seen. Accordingly, increased urinary TNF- $\alpha$ level during relapse without increments of plasma TNF- $\alpha$ and no change in BM HSPG gene expression and HS synthesis means that TNF- $\alpha$ may not play a primary role in the pathogenesis of $\mathrm{MCD}$, and its elevation in the urine could be a secondary event.

In summary, although plasma and urinary IL-8 increased in children with MCD during relapse, IL-8 did not alter the permeability of GEC monolayers, BM HSPG gene expression and HS synthesis in the GECs. TNF- $\alpha$ was increased in urine, not in plasma, during relapse without change in the permeability of GEC monolayers, BM HSPG gene expression and HS synthesis in the GECs. Therefore, it seems that IL-8 could be one of many unknown cytokines capable of increasing the glomerular permeability to albumin in patients with MCD; however, its potency as a permeability factor seems to be very weak. TNF- $\alpha$ does not seem to play a disease-specific role in the pathogenesis of MCD; rather, its change seems to be secondary to nephrotic syndrome itself.

\section{Acknowledgement}

This study was supported by a grant from the Biomedical Research Institute of Kyungpook National University (2002). A part of this study was presented at the Annual Meeting of the American Society of Nephrology, Philadelphia, Pennsylvania, November 2002.

\section{References}

1 A Report of the International Study of Kidney Disease in Children: Primary nephrotic syndrome in children: Identification of patients with minimal change nephrotic syndrome from initial response to prednisone. J Pediatr 1981; 98:561-564.

2 Sewell RF, Short CD: Minimal-change nephropathy: How does the immune system affect the glomerulus? Nephrol Dial Transplant 1993;8:108-112.
3 Koyama A, Fujisaki M, Kobayashi M, Igarashi M, Narita M: A glomerular permeability factor produced by human $\mathrm{T}$ cell hybridomas. Kidney Int 1991;40:453-460.

4 Guasch A, Deen WM, Myers BD: Charge selectivity of the glomerular filtration barrier in healthy and nephrotic humans. J Clin Invest 1993;92:2274-2282.

5 Guasch A, Hashimoto H, Sibley RK, Deen WM, Myers BD: Glomerular dysfunction in nephrotic humans with minimal changes or focal glomerulosclerosis. Am J Physiol 1991; 260:F728-737.
6 Wilkinson AH, Gillespie C, Hartley B, Gwyn Williams D: Increase in proteinuria and reduction in number of anionic sites in the glomerular basement membrane in rabbits by infusion of human nephrotic plasma in vivo. Clin Sci (Colch) 1989;77:43-48.

7 Zimmerman SW: Increased urinary protein excretion in the rat produced by serum from a patient with recurrent focal glomerular sclerosis after renal transplantation. Clin Nephrol 1984;22:32-38. 
8 Boulton Jones JM, Tulloch I, Dore B, McLay A: Changes in the glomerular capillary wall induced by lymphocyte products and serum of nephrotic patients. Clin Nephrol 1983;20:7277.

9 Yoshizawa N, Kusumi Y, Matsumoto K, Oshima S, Takeuchi A, Kawamura O, Kubota T, Kondo S, Niwa H: Studies of a glomerular permeability factor in patients with minimalchange nephrotic syndrome. Nephron 1989;51: 370-376.

10 Maruyama K, Tomizawa S, Shimabukuro N, Fukuda T, Johshita T, Kuroume T: Effect of supernatants derived from $\mathrm{T}$ lymphocyte culture in minimal change nephrotic syndrome on rat kidney capillaries. Nephron 1989;51:7376.

11 Tanaka R, Yoshikawa N, Nakamura H, Ito H: Infusion of peripheral blood mononuclear cell products from nephrotic children increases albuminuria in rats. Nephron 1992;60:35-41.

12 Koyama A, Fujisaki M, Kobayashi M, Igarashi M, Narita M: A glomerular permeability factor produced by human $\mathrm{T}$ cell hybridomas. Kidney Int 1991;40:453-460.

13 Cheung PK, Dejkhuis FWJ, Bakker WW: The endothelial cell as potential target for a human vasoactive plasma factor associated with minimal change nephrotic syndrome (abstract). J Am Soc Nephrol 1995;6:656.

14 Garin EH, Blanchard DK, Matsushima K Djeu JY: IL-8 production by peripheral blood mononuclear cells in nephrotic patients. Kidney Int 1994:45:1311-1317.

15 Neuhaus TJ, Wadhwa M, Callard R, Barrat HTM: Increased IL2, IL4 and interferon-gamma $($ IFN- $\gamma)$ in steroid-sensitive nephrotic syndrome. Clin Exp Immunol 1995;100:475-479.

16 Bustos C, Gonzalez E, Muley R, Alonso JL, Egido J: Increase of tumor necrosis factor alpha synthesis and gene expression in periphera blood mononuclear cells of children with idiopathic nephrotic syndrome. Eur J Clin Invest 1994;24:799-805.

17 Yoshimura TR, Matsushima K, Oppenheim JJ, Leonard EJ: Neutrophil chemotactic factor produced by lipopolysaccharide (LPS)-stimulated human blood mononuclear leukocytes: Partial characterization and separation from interleukin 1(IL-1). J Immunol 1987;139:788793.

18 Matsumoto K: IL-8 release from cultured peripheral blood monocytes of patients with glomerulonephritis. Clin Exp Immunol 1995;99: 106-111.

19 Garin EH, West L, Wang Z: Effect of interleukin 8 on glomerular sulfated compounds and albuminuria. Pediatr Nephrol 1997;11:274279.

20 Wardle EN: Cytokine growth factors and glomerulonephritis. Nephron 1991;57:257-261.
21 Noble B, Ren K, Taverne J, Dipirro J, Van Liew J, Dijkstra C, Janossy G, Poulter LW: Mononuclear cells in glomeruli and cytokines in urine reflect the severity of experimental proliferative immune complex glomerulonephritis. Clin Exp Immunol 1990;80:281-287.

22 Wardle EN: Cell biology and glomerulonephritis. Nephron 1991;59:529-532.

23 Tipping PG, Leong TR, Holdsworth ST: Tumor necrosis factor production by macrophages in anti-glomerular basement membrane glomerulonephritis in rabbits. Lab Invest 1991; 65:272-279.

24 Kreisberg JL, Hoover RL, Karnovsky MJ: Isolation and characterization of rat glomerular cells in vitro. Kidney Int 1978;14:21-30.

25 Hammes M, Singh A: Effect of polycations on permeability of glomerular epithelial cell monolayers to albumin. J Lab Clin Med 1994; 123:437-446.

26 Singh AK, Mo W, Dunea G, Arruda JAL: Effect of glycated proteins on the matrix of glomerular epithelial cells. J Am Soc Nephrol 1998;9:802-810.

27 Pegoraro AA, Singh AK, Arruda JAL, Dunea G, Bakir AA: A simple method to detect an albumin permeability factor in the idiopathic nephrotic syndrome. Kidney Int 2000;58: 1342-1345.

28 Chomczynski P, Sacchi N: Single step method of RNA isolation by acid guanidinium thiocyanate-phenol-chloroform extraction. Anal Biochem 1987;162:156-159.

29 Noonan DM, Fulle A, Valente P, Cai S, Horigan E, Sasaki M, Yamada Y, Hassell JR: The complete sequence of perlecan, a basement membrane heparan sulfate proteoglycan, reveals extensive similarity to laminin A chain, low density lipoprotein receptor and the neural cell adhesion molecule. J Biol Chem 1991;266: 22939-22947.

30 Kallunki P, Tryggvason K: Human basement membrane heparan sulfate proteoglycan core protein: A $467 \mathrm{kD}$ protein containing multiple domains resembling elements of the low density lipoprotein receptor, laminin, neural cell adhesion molecule and epidermal growth factor. $\mathrm{J}$ Cell Biol 1992;116:559-571.

31 Ledbetter SR, Tyree B, Hassell JR, Horigan EA: Identification of precursor protein to basement membrane heparan sulfate proteoglycan. J Biol Chem 1985;260:8106-8113.

32 Cheung PK, Klok PA, Baller JF, Bakker WW: Induction of experimental proteinuria in vivo following infusion of human plasma hemopexin. Kidney Int 2000;57:1512-1520.
33 Cheung PK, Stulp B, Immenschuh S, Borghuis $\mathrm{T}$, Baller JF, Bakker WW: Is $100 \mathrm{KF}$ an isoform of hemopexin? Immunochemical characterization of the vasoactive plasma factor $100 \mathrm{KF}$. J Am Soc Nephrol 1999;10:1700-1708.

34 Garin EH: Effect of lipoid nephrosis cytokine on glomerular sulfated compounds and albuminuria. Pediatr Nephrol 1995;9:587-593.

35 Nakanishi I, Montabarrick A, Okada N, Kitamura E, Hayashi A, Syouji T, Namiki M, Ishibashi M, Zaid D, Tsubakihara Y: Interleukin-8 in chronic renal failure and dialysis patients. Nephrol Dial Transplant 1994;9:1435-1442.

36 Wada T, Yokoyama H, Tomosugi N, Hisada Y, Ohta S, Naito T, Kobayashi K, Mukaida N, Matsushima K: Detection of urinary interleukin-8 in glomerular diseases. Kidney Int 1994; 46:455-460.

37 Ko CW, Bhandari B, Yee J, Terhune WC, Maldonado R, Kasinath BS: Cyclic AMP regulates basement membrane heparan sulfate proteoglycan, perlecan, metabolism in rat glomerular epithelial cells. Mol Cell Biochem 1996;162: 65-73.

38 Garin EH, West L, Blanchard K, Matsushima K, Djeu JY: Effect of sulfate uptake by the glomerular basement membrane. Nephron 1995; 71:442-447.

39 Narita J, Morioka T, Yoshida K: Monocytes secrete factors that regulate glycosaminoglycan synthesis by mesangial cells in vitro (abstract). Kidney Int 1989;35:357.

40 Ko CW, Koo JH, Chang HJ, Kasinath BS: Permeability factor which was drawn from children with minimal change disease reversibly suppresses glomerular basement membrane heparan sulfate proteoglycan mRNA expression in rats glomerular epithelial cells (abstract). J Am Soc Nephrol 1999;10:106A.

41 Singh AK, Mo W, Dunea G, Arruda JAL: Effect of glycated proteins on the matrix of glomerular epithelial cells. J Am Soc Nephrol 1998;9:902-910.

42 Raats CJI, van den Born J, Berden HM: Glomerular heparan sulfate alterations: Mechanisms and relevance for proteinuria. Kidney Int 400;57:385-400.

43 Suranyi MG, Guasch A, Hall BM, Myers BD Elevated levels of tumor necrosis factor-alpha in the nephrotic syndrome in humans. Am J Kidney Dis 1993;21:251-259.

44 Nakamura T, Miller D, Ruoslahti E, Border WA: Production of extracellular matrix by glomerular epithelial cells is regulated by transforming growth factor- $\beta 1$. Kidney Int 1992; 41 : 1213-1221.

45 Shewring L, Thomas GJ, Davies M: Proteoglycan synthesis is stimulated by TNF in rat mesangial cell in vitro (abstract). Clin Sci 1989; 76(suppl):20 